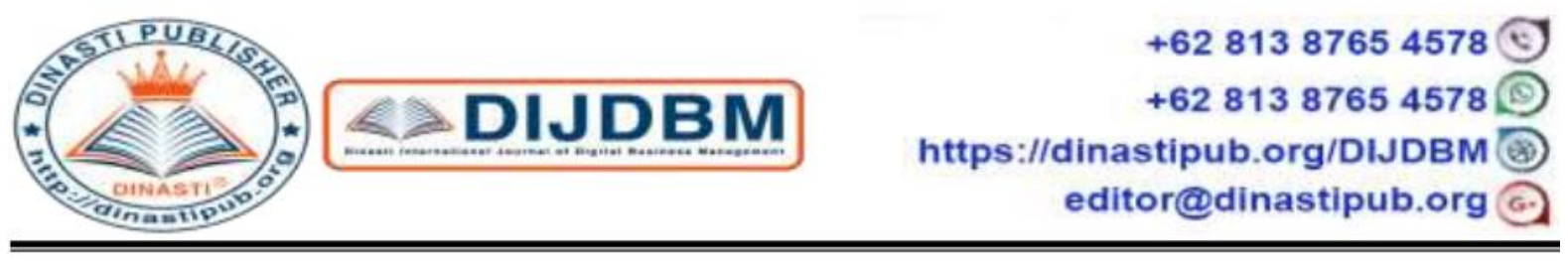

\title{
THE ADVANTAGES OF IMPLEMENTATION OF INTEGRATED MANAGEMENT SYSTEM ON ISO45001, AND ISO14001 IN MANUFACTURING INDUSTRY
}

Yuni Pratikno'), Kusnadi ${ }^{2)}$

${ }^{1,2)}$ Sekolah Tinggi Manajemen IMMI Jakarta

\begin{tabular}{|c|c|}
\hline $\begin{array}{c}\text { ARTICLE INFORMATION } \\
\text { Received: } 18^{\text {th }} \text { March } 2020 \\
\text { Revised: } 19^{\text {th }} \text { April } 2020 \\
\text { Issued: } 30^{\text {th }} \text { April } 2020 \\
\text { Corresponding author: Yuni } \\
\text { Pratikno } \\
\text { E-mail: } \\
\text { yuni.pratikno@gmail.com } \\
\text { hamas_kus@yahoo.com }\end{array}$ & $\begin{array}{l}\text { Abstract: Integrated management system (IMS) can } \\
\text { integrate several management systems in companies } \\
\text { such as: Environmental Management Systems (ISO } \\
\text { 14001) and Occupational Health and Systems Safety } \\
\text { Management (ISO45001). The purpose of this study is } \\
\text { to answer the question of what and how to implement } \\
\text { IMS policies in industrial companies in the fields of } \\
\text { occupational safety, occupational health and } \\
\text { environmental sustainability. This IMS implementation } \\
\text { research was conducted on a manufacturing industry } \\
\text { that has implemented IMS. The research method is } \\
\text { conducted with qualitative methods with CIPP } \\
\text { evaluative model (Context, Input, Process, and } \\
\text { Product). This study succeeded in uncovering the } \\
\text { implementation of IMS in the manufacturing industry } \\
\text { which was investigated that the IMS had been fully } \\
\text { implemented in the Occupational Health and } \\
\text { Environmental Management and Safety System (HSE). } \\
\text { The IMS is implemented at the policy level or } \\
\text { management commitment (context), HSE planning } \\
\text { (Input), operational implementation (process), HSE } \\
\text { monitoring and evaluation and a review (Product) for } \\
\text { continuous performance improvement. } \\
\text { Keywords: System, Management, Integrated, Industry } \\
\text { Manufacturing }\end{array}$ \\
\hline
\end{tabular}

\section{INTRODUCTION}

The development of information and communication technology (ITC) in the world order of life now accelerates the process of globalization in all aspects of economic life that forms a new world with boundaries between countries that are increasingly transparent and blurred. The influence of rapid ICT development and globalization is not only limited to the formation of a global market of products and services but also a production system that is global in mind. Consumers, especially for export goods, require compliance with regulations, implementation of international organization standards on quality management, 
environmental management standards, occupational health and safety standards and other international standards in an integrated manner. The occupational safety and health and environmental management system (HSE) and other international standards are standard requirements that must be owned by the company before consumers, especially the global market, buy the products they produce. Integrated HSE implementation has even become a necessity for today's business world where customer companies require certification in the HSE management system and international management systems. The researcher used the PDCA Management Cycle theory (Plan, Do, Check and Action) proposed by CIPP's Demming and policy model (Context, Input, Process and Product) which was put forward by Daniel Stufflebeam, the combination of the two models is seen in the picture below.

Figure 1. Key Component of CIPP Model of Evaluation

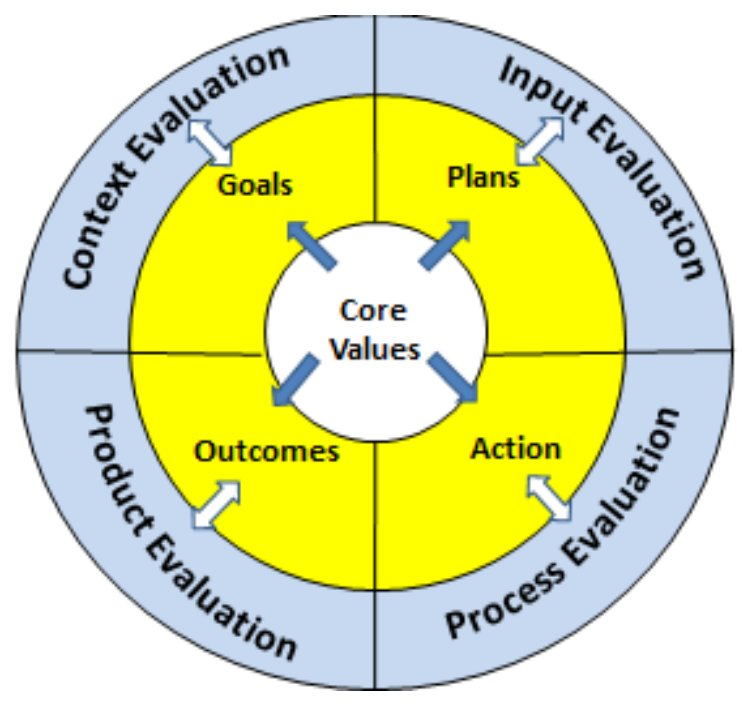

Source :Daniel Stufflebeam, Evaluation Theory Models And Application.

Previous research conducted in December 2002 of around 560,000 ISO 9000 certificates was issued in 159 countries (Jorgensen, Mellado, and Remmen, 2005). Jorgensen discovered that the implementation of IMS for the quality management system was integrated with the environmental management system in European countries he was researching. Holdsworth (2003) in his research has found the implementation of IMS in petro chemical industry companies and chemical companies. Holdsworth (2003) found a large difference between the safety regulation process, the risk management program standard developed in environmental management standards in the United States and quality management standards developed by the International Standards Organization. Arifin et al., (2006, 2008), in a study at a university in Malaysia found that the quality management system, occupational safety and health and environmental management systems have been fully integrated, the organization combines all parts and sub-sections in each management system become a new integrated management system. In summary, it can be seen in Figure 2 below. 


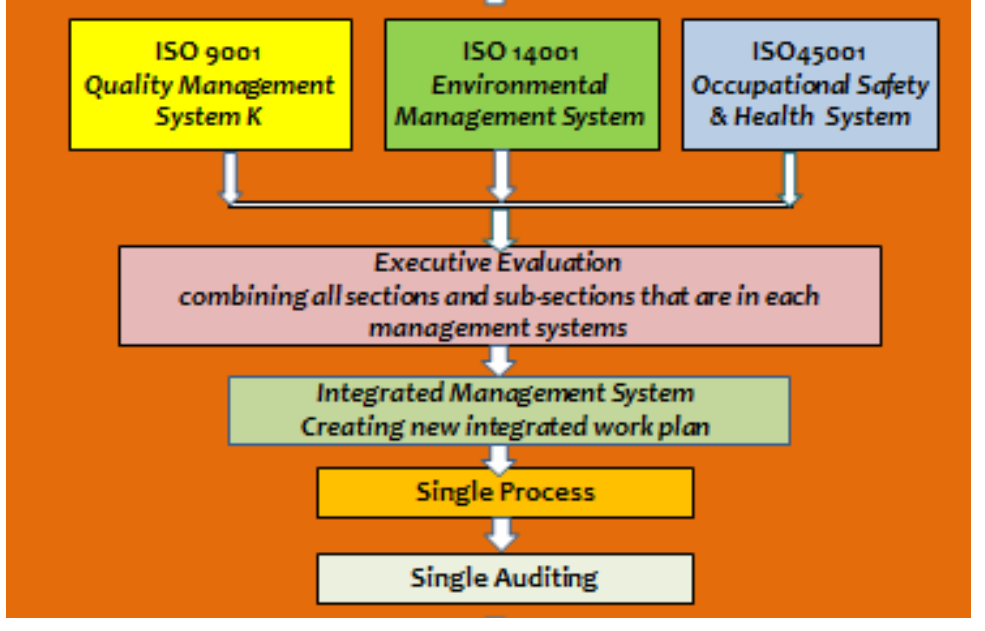

Source modified : Kadir Arifin Universiti Kebangsaan Malaysia)

When these management systems have been combined, the process of implementing and auditing each system will become a whole by itself. The article in this study was conducted to obtain data, facts, and information about the integrated safety, health and work environment (HSE) management system in the manufacturing industry companies studied. This article aims to get answers to how the results of this study can be used to solve the problems of IMS implementation in the manufacturing industry companies studied including the implementation of an integrated management system in the integrated HSE field. This article is expected to be a guide for the manufacturing industry in particular and become a contribution of thought to the scientific world in general.

\section{RESEARCH METHODS}

This article is written based on research carried out on a manufacturing industry that has implemented an integrated HSE management system policy. This company has implemented an environmental management system, occupational health and safety management system, The journey process of implementing all of these management systems eventually arrived at an integrated management system (IMS). This article is written based on research starting from field observations, collecting data through documents, interviews, group discussions, data analysis, and evaluation and ending with the making of the report. The study was conducted from 7 January 2019 to 25 June 2019. This research is a qualitative research, which is research with the characteristics of using natural settings, is descriptive, emphasizes the process, using an inductive approach, and gives attention to the meaning

The reason for using the qualitative approach in this study is based on the facts that have occurred in the implementation of HSE management system policies in the company. Research in these manufacturing companies is not a sample subject, so the conclusions produced cannot be generalized.

Content evaluation techniques are used as a frame by researchers in collecting data through interviews, grouping and framing the answers of resource persons, and evaluating qualitative findings. All equipment used to obtain, process and interpret information from respondents conducted in the same measurement pattern. The purpose of using the instrument is as a tool for recording information from respondents, organizing the interview process, and evaluating the work performance of researchers. The theoretical review process of a concept starts from the evaluation component, the aspect that is evaluated, the indicator to the 
translation and writing of the instrument item. The researcher explains the experts who examine the instruments, study procedures and results of the study qualitatively. Next the researcher explained the study procedure and the results of the panel validation test qualitatively as well. In testing the validity of the data, the researcher used triangulation technique, which is the technique of checking the validity of data that uses something else (Moloung, 2004). Data collection techniques used will complement in obtaining primary and secondary data, while observations and interviews are used to capture primary data relating to the evaluation of IMS policy implementation in a manufacturing company. To capture secondary data can be raised through various documentation about the perspective of implementation and policy outcomes.

Data collection techniques from primary and secondary and tertiary data sources conducted by researchers include interviews about regulations, government and company policies on IMS (context); planning and systems of IMS procedures (input); implementation of IMS operations (process); IMS monitoring and evaluation ( product), and review of IMS. Observations were made to get an overview of the implementation of IMS from direct observations in industrial companies regarding IMS symbols, work culture based on IMS and management behavior, and company employees. Document review is carried out on written policy documents about IMS, operational procedure documents, work instructions, monitoring and evaluation results documents and continuous improvement plans. Researchers conducted interviews with interview guidance instruments for regulators from the PNKK Director of the Ministry of Manpower, and the Head of the Regional Environmental Agency of DKI Jakarta, the ranks of directors, managers, supervisors and employees in a manufacturing industry. The researcher presents data collection techniques in the form of tables or charts which include evaluation components, evaluated aspects, data sources, instruments used and data sources, data collection techniques and types of instruments used.

\section{RESULTS}

\section{Implementation of HSE IMS}

Based on the results of an interview regarding the regulation of IMS in the field of employment with one of the Officials of the Directorate of Norm Supervision of Work Safety (PNKK) Ministry of Manpower of the Republic of Indonesia. The question asked was "How is the regulation of the implementation of IMS in the field of occupational safety and health integrated with other company management systems?". It was found that the provisions concerning the implementation of the Occupational Health and Safety Management system in an integrated manner with other management systems were stated in Article 87 paragraph (1) that "Every company is obliged to implement an occupational safety and health management system that is integrated with the company's management system" and Government Regulation No. 50 of 2012 concerning the Implementation of Occupational Safety and Health Management Systems. Evidence that the company has implemented an integrated work safety and occupational health management system with other management systems in the form of ISO45001 certificates issued by independent institutions authorized to audit and issue certificates. The provisions concerning integration mentioned above according to the HSE Director contain the understanding that there is inherent supervision of the top management of the Company through the HSE organizational structure which is under its control directly and unevenly or similar to other functional organizational structures. 
The placement of the HSE organizational structure that meets the criteria in an integrated manner is located at the neck of the top management. The establishment of representative / MR management in charge of the HSE is above the division head, department head or section head in the company's organizational structure. The placement of the organizational structure as mentioned above allows all functions in the organization to comply because it is in a higher position than the division or departmental functions in the organization. Based on the results of interviews with one of the MR in charge of quality management and material safety in the company under study, it was found that the MR organizational structure was under the head of the operating division. Based on the results of the research report on the Committee for Safety and Health Guidance Committee submitted by the company to the Ministry of Manpower and Transmigration, there are still many companies that have not placed OHS organizations on the neck of top management, consequently the OHS organization cannot carry out its functions effectively because of policies and the programs lack serious attention and are still seen as a cost center not a center of profit.

According to one company official in charge of management integration, it was found that the company had implemented the HSE from a written document setting the OHSE policy (context); (2) HSE planning documents in the form of operating procedures (input) and implementation (process); (3) document on the implementation of HSE plan; (4) documents resulting from the monitoring and performance evaluation of OHSE (product); and (5) document of OHSL performance review and improvement. The company's policy is "Ensuring as a leading flavoring and fragrance industry in Indonesia, Asia, in the world by improving integrated management systems (ISO 14001; ISO45001;) on an ongoing basis to fulfill customer satisfaction, guarantee products safe food, reduce the level of work accidents that are as small as possible as well as very concerned with the condition of the initial environmental tone ".

The results of the interviews with the Board of Directors and the manufacturing industry employees examined found that the Company had appointed a management representative (MR) in coordinating and managing the integration management system, covering the entire HSE activities, in accordance with the direction of top management as outlined in the Integration Operational Policy and Procedure as stated in the Integration Manual and company Manual Procedures. Based on the operational procedure document, the duties and responsibilities of MR companies in general are as follows: a) Ensure that timely and effective actions are carried out by the appropriate departments to maintain the integrity of the Integration system; b) Analyze the system of integration of organizations and programs; c) Establish and maintain a system of corrective and preventive actions to ensure effective handling of the deficiency of the Integration system; d) Ensuring documentation of the integration management system is always actual.

The results of the interview with the MR in the company under study obtained information that the Management Representative of the company was conducted by person which functions as MR for ISO 14001: 2014 and ISO45001. MR for HSE is held by a section that specifically handles OHSL implementation, namely EHS Manager. Based on the company's operational documents and job description documents found EHS Manager duties and responsibilities include the following: a) Ensure that the occupational safety and health and environmental systems are effective within the organization based on the direction of the Global Regulatory Affair; b) Develop an occupational safety and health and environmental management system based on Regional and Global Safety directives; c) Implementing a 
system of occupational safety and health and the environment in collaboration with the head of function; d) Appoint an auditor team to monitor and verify the HSE system.

The condition of the HSE IMS in a manufacturing industry studied was illustrated visually in Figure 2 showing the pattern of integration between SMOHS and environmental management. In the diagram, it can be seen that integration 3 of the management system in the manufacturing industry has integrated the process from starting from initial review or review, policy setting, implementation of HSE policy and monitoring or supervision and improvement of sustainable HSE performance.

Figure 3 Integrated Management System (IMS)

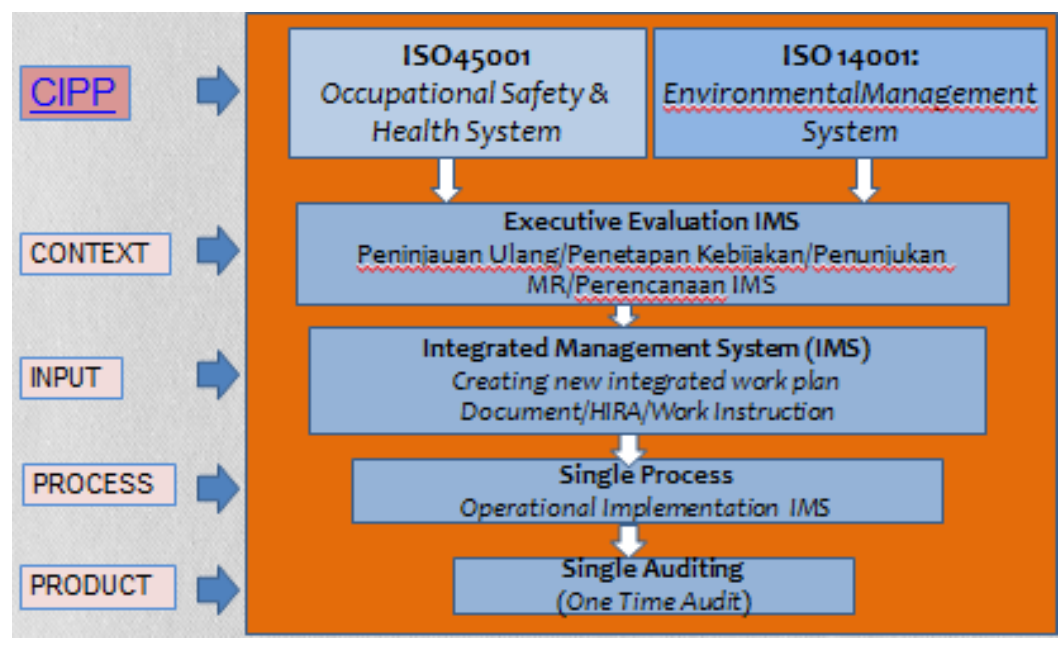

Source Modified : INTEGRATED ISO45001-ISO14001

The integration of IMS IMS policy implementation and environmental management in the manufacturing industry under study has been implemented and has been integrated both in terms of policy settings (context), HSE planning (input), HSE operational implementation (process), HSE measurement and supervision, and review (product) and continuous improvement in HSE performance.

The combination of the Demming management cycle model and the Daniel Stufflebem Analysis model can produce a match between the two models in the HSE evaluation through the first, second and third circles as shown in Figure 4 bellow. 




Key Component of CIPP Model of Evaluation \& ISO45001/ISO14001

Some documents that have been integrated include independent audits, training procedures, and review management, while procedures can still be done because there are significant differences that cannot be done electronically. Based on the results of interviews with the ranks of manufacturing companies that were examined that the management of the work system, occupational health and environmental management systems were integrated. The implementation of the IMS is used because the company's management is to become representative management (MR) for these systems.

The results of the results of the results of the determination of Placement from HSE become more assertive and focused. Regarding setting MR on the organizational structure and under the president director shows the company's commitment (leadership) in accordance with national policies on the application of management and work systems in accordance with PP No. 50 of 2012 as shown in Figure 5.

\section{Struktur Organisasi}

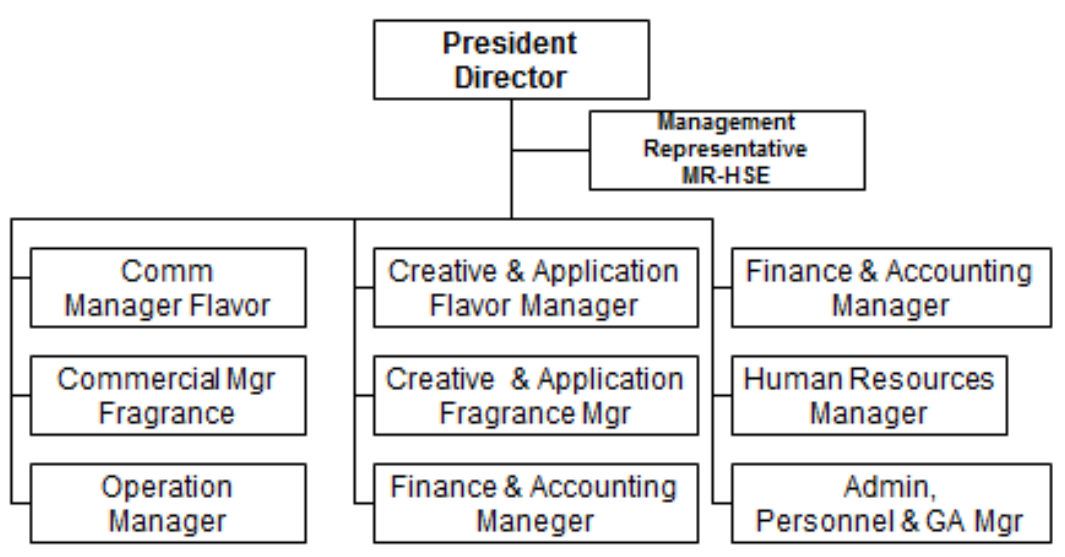




\section{FINDINGS AND DISCUSSION \\ Implementation of IMS HSE}

Comparing the results of IMS HSE research with relevance, the integration between OHS and environmental management systems has shown similarities in the concept of integrated management systems in the manufacturing industry under study. By combining the CIPP model and the management cycle and the HSE cycle, the IMS has the suitability of the models of both as shown in the table below.

\begin{tabular}{|c|c|c|c|c|}
\hline No & Description & $\begin{array}{l}\text { Evaluation } \\
\text { Model } \\
\text { CIPP }\end{array}$ & $\begin{array}{l}\text { PDCA Cycle } \\
\text { /ISO45001 } \\
\text { /OHS/ISO14001- } \\
\text { Cycle HSE }\end{array}$ & Evaluation with combine approach \\
\hline 1 & Core ring & Core Value & Vission/Mission & $\begin{array}{l}\text { There is a match between Core Value, } \\
\text { Vision and Mission }\end{array}$ \\
\hline \multirow[t]{4}{*}{2} & \multirow[t]{4}{*}{ Mid ring } & $\begin{array}{l}\text { Policy/ } \\
\text { Objectives }\end{array}$ & Action/Improvement & $\begin{array}{l}\text { There is an interplay between the policy } \\
\text { setting and the CIPP with an increase in } \\
\text { actions resulting from PDCA }\end{array}$ \\
\hline & & Plan & Plan & $\begin{array}{l}\text { Appears in CIPP's inner circle with plans in } \\
\text { PDCA }\end{array}$ \\
\hline & & Action & Do & $\begin{array}{l}\text { There is an expression of the balance } \\
\text { between the actions in the second circle of } \\
\text { CIPP with Do in PDCA }\end{array}$ \\
\hline & & Outcomes & Check & $\begin{array}{l}\text { Look at the compatibility between the results } \\
\text { of the CIPP's second circle by checking / } \\
\text { monitoring \& monitoring the product in } \\
\text { PDCA }\end{array}$ \\
\hline \multirow[t]{4}{*}{3} & \multirow[t]{4}{*}{$\begin{array}{l}\text { Ouside } \\
\text { ring }\end{array}$} & Contect & First Review/final & $\begin{array}{l}\text { There is an evaluation context commercial } \\
\text { from CIPP with HSE IMS / Cycle information }\end{array}$ \\
\hline & & Input & Setting policy & $\begin{array}{l}\text { There is a suitability of the Input evaluation } \\
\text { from CIPP with the Policy Determination of } \\
\text { the HSE Cycle }\end{array}$ \\
\hline & & Process & $\begin{array}{l}\text { Implementation } \\
\text { policy }\end{array}$ & $\begin{array}{l}\text { There was a scoring between the Evaluation } \\
\text { Process at CIPP with Policy Implementation } \\
\text { on the HSE }\end{array}$ \\
\hline & & Output & $\begin{array}{l}\text { Monitoting and } \\
\text { evaluation }\end{array}$ & $\begin{array}{l}\text { Seen the agreement between the Output } \\
\text { Evaluation on CIPP with the inspection / } \\
\text { supervision of results in the IMS HSE cycle }\end{array}$ \\
\hline
\end{tabular}

Information system management is a management system that serves to represent the two management of its formation. Based on the research of Arifin K. et. Al. (2009) revealed by means of integration, the organization would combine all parts and sub-sections of each management system into a new integrated management system. Integration starts from policy setting, HSE planning which describes the executive evaluation section, the implementation 
of the HSE which is described as an integrated management system, SOP-SOP, HSE monitoring and supervision which is defined as a single audit or one-time inspection for certification, and a re-viewer and performance improvement sustainable which is described as a single process or one time activity. With one audit, a one-time activity will allow a very large yield and efficiency for the company. Integration that can save time, labor requirements, and costs for implementing the system. However, what happened as the researcher described above is still partial only from 2 management systems that have been successful, namely one side to implement IMS in the fields of safety, health and the environment and on the other hand IMS implementation in the field of quality management and management. Integration of integration integration among groups of groups group system group system which is the one that is the University of Malaysia, as describe in bellow figure 6

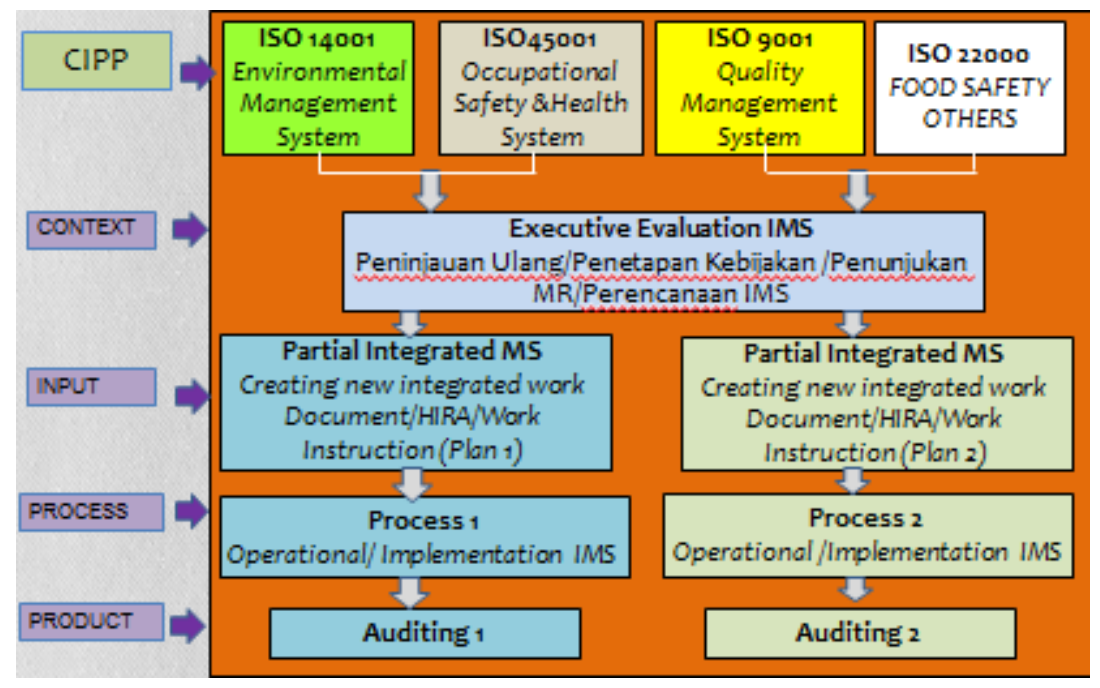

In order to be fully integrated with the stand-alone HSE / MR organizational structure for departments or offices that are specifically for HSE do not hold offices. EHS organization concurrently as MR EHS so that there is no dualism of leadership in the organization. MR EHS will appear firmly in a company structure that is not what it is today. OHS/HSE Department lead by HSE Manager / MR on company management systems.

\section{CONCLUSION AND SUGGESTION}

Integration of OHS IMS policy implementation and environmental management in the manufacturing industry that has been studied has been carried out effectively and efficiently and has been fully integrated both in the aspects of policy setting, HSE planning, HSE operational implementation, HSE measurement and supervision, as well as OHSE performance review and improvement sustainable. The integration of the three system fields in full in this researched manufacturing company has brought the company to a good performance that will at least be able to reduce the rate of workplace accidents, prevent occupational diseases and prevent the degradation of environmental quality. Some of the documents that have been integrated include independent audits, training procedures, record control procedures, and management reviews, while other procedures cannot be implemented because of significant differences that cannot be fully integrated.

It is recommended that the Management Representative of management systems be integrated under the Top Management organization structure as to allow savings in some cases including costs will be reduced, documentation will be simpler, processes and audits 
can be done at the same time so that it can save a lot of time and costs as discribed in the figure 7 bellow.

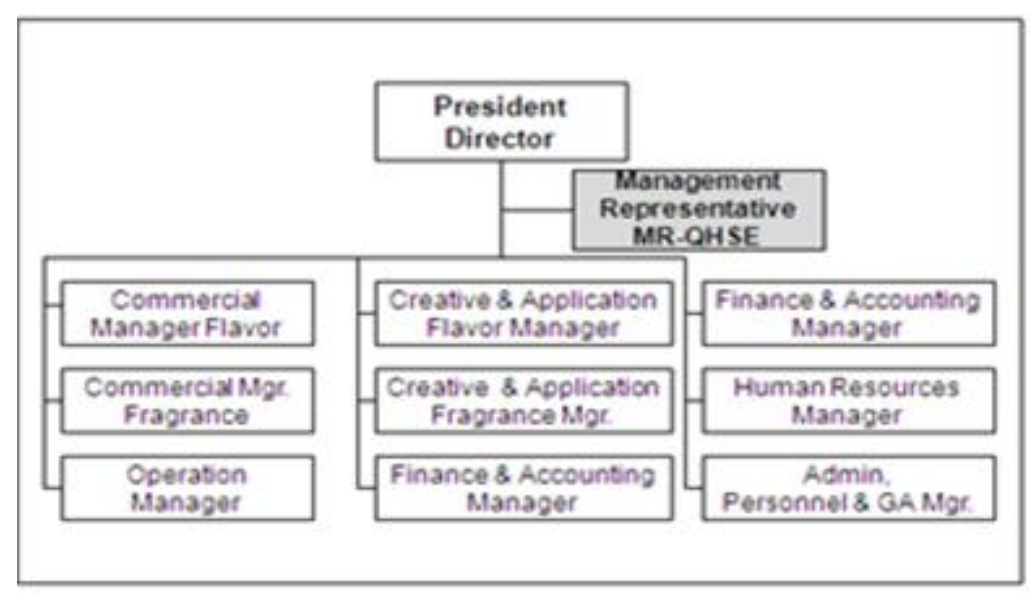

The integration of Health, Safety (ISO 45001, OHS) and Environmental Management (ISO14001) system management is something that can be incorporated in one document as has happened in previous relevant research results in other organizations so that IMS will be more effective and efficient in its application as discrib in figure 8 bellow.

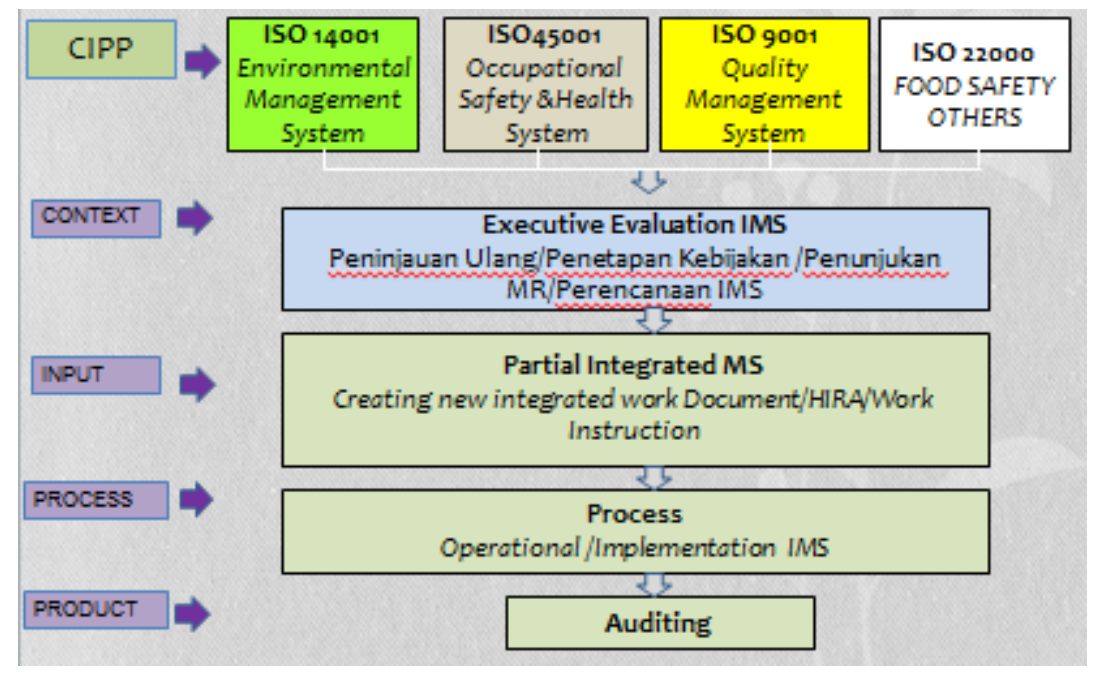

Source Modified : Full Intregrated Model

It is recommended that manufacturing industry to implemen full integrated become one IMS system Safety (ISO 45001, OHS) and Environmental Management (ISO14001), ISO 9001, ISO 22001 and other system management in place.

\section{REFERENCE}

Creswell, John W. Research Design : Pendekatan Kualitatif, Kuantitatif, dan Mixed, Yogyakarta: Pustaka Pelajar, 2010. 
Widoyoko, Eko Putro. Evaluasi Program Pembelajaran: Panduan Praktis Bagi Pendidik dan Calon Pendidik. Yogyakarta: Pustaka Pelajar, 2011

Gaspersz, Vincent. Three in one ISO 9001, ISO 14001, OHSAS 18001, Sistem Manajemen Kualitas, OHS, Lingkungan (HSE) dan Peningkatan Kinerja Terus Menerus, Bogor: Vinchristo Publication, 2012

Moleong, Lexy J. Metodologi Penelitian Kualitatif, Bandung: PT. Putra Remaja Rosdakarya, 2011.

Quinn, Michael Patton. Metode Evaluasi Kualitatif, Yogyakarta: Pustaka Pelajar, 2009.

Ramli, Soehatman. Sistem Manajemen Keselamatan dan Kesehatan Kerja-OHSAS 18001, Jakarta: Dian Rakyat, 2010.

Riyanto, Boedi. Pedoman Praktis Keselamatan, Kesehatan Kerja Dan Lingkungan (OHSL) Industri Konstruksi, Jakarta : Mitra Wacana Media, 2010.

Simanjuntak, Payaman. Manajemen Hubungan Industrial, Jakarta : Fakultas Ekonomi Universitas Indonesia, 2011

Stufflebeam, D.L., Shinkfield, A.J. Evaluation Theory, Models, And Application, San Francisco: John Wiley \& Sons, Inc 2007.

Arifin, K (2009). Implementation of Integrated Management System in Malaysia: The Level of Organization's Understanding and Awareness, European Journal of Scientific Research ISSN 1450-216X 31(2), pp.188-195 http://www.eurojournals.com/ejsr.htm, di akses 8 Mei 2019.

Jørgensen, T.H. Mellado, M.D. Remmen A. Integrated Management systems, http://www.plan.aau.dk. (Aalborg University : 2004). Diakses 8 Mei 2012.

International Labor Organization. OHS Management System : A toll for contiual improvement, , http://www.ilo.org, diakases 28 April 2019.

Holdsworth, Rodger (2003). Practical applications approach to design, development and implementation of an integrated management system, Journal of Hazardous Materials :104, New Orleans, LA, diakses 5 April 2019.

Sumaedi Sik, et. al. Studi Penerapan Sistem Manajemen Terintegrasi ISO 9001 dan ISO 14001 pada Distributor Truk Berat. Diakses 23 Desember 2019. 